\title{
Sorption Profile of Cd(II) Ions onto Beach Sand from Aqueous Solutions.
}

\author{
Syed Iqleem Haider Taqvi ${ }_{2}^{1}$, Syed Moosa Hasany ${ }^{2,}$, Mohammad Iqbal Bhanger ${ }^{1}$, \\ ${ }^{1}$ Center of Excellence in Analytical Chemistry University of Sindh, Jamshoro, Pakistan. \\ ${ }^{* 2}$ Pakistan Institute of Nuclear Science and Technology, PO Nilore. Islamabad, Pakistan.
}

\begin{abstract}
Sorption of traces of $\mathrm{Cd}(\mathrm{II})$ ions onto beach sand is investigated as a function of nature and concentration of electrolyte $\left(10^{-4}-10^{-2} \mathrm{M}\right.$ nitric, hydrochloric and perchlororic acids, $\mathrm{pH}$ 2-10 buffers and deionized water), shaking time (5-40 minutes), shaking speed (50-200 strokes per minute), dosage of sand (50-1000 mg/ $\left.15 \mathrm{~cm}^{3}\right)$, concentration of sorbate $\left(1.04 \times 10^{-6}-1.9 \times 10^{-4} \mathrm{M}\right)$ and temperature (293-323K). Maximum sorption of $\mathrm{Cd}(\mathrm{II})$ ions $(-66 \%)$ is achieved from deionized water using $300 \mathrm{mg} / 15 \mathrm{~cm}^{3}$ sand in 20 minutes. The data are successfully tested by Langmuir, Freundlich and Dubinin-Redushkevich (D- R) sorption isotherms. The values for characteristic Langmuir constants $Q=13.31 \pm 0.20 \mu \mathrm{mole} / \mathrm{g}$ and $\mathrm{b}=(6.56 \pm 0.53) \times 10^{3} \mathrm{dm}^{3} / \mathrm{mole}$, Freundlich constants: $\mathrm{A}=2.23 \pm 1.16 \mathrm{~m} \mathrm{~mole} / \mathrm{g}$ and $1 / \mathrm{n}=0.70 \pm 0.05,(\mathrm{D}-\mathrm{R})$ constants $\beta=$ $0.005068 \pm 0.000328 \mathrm{~kJ}^{2} / \mathrm{mole}^{2}, X_{m}=46.91 \pm 11.91 \mu \mathrm{mole} / \mathrm{g}$ and energy $E=9.92 \pm 0.32 \mathrm{~kJ} / \mathrm{mole}$ have been estimated. Kinetics of sorption were studied by applying Morris-Weber, Reichenberg and Lagergren equations. The sorption follows first order rate equation with $\mathrm{k}=0.182 \pm 0.004 \mathrm{~min}^{-1}$ The thermodynamic parameters $\Delta \mathrm{H}=32.09 \pm 2.92 \mathrm{~kJ} / \mathrm{mole}, \Delta \mathrm{S}=111.0 \pm 9.5 \mathrm{~J} / \mathrm{moleK}$ and $\Delta \mathrm{G}=-1.68 \pm 0.02 \mathrm{~kJ} / \mathrm{mole}$ are evaluated. The influence of common ions on the sorption of $\mathrm{Cd}(\mathrm{II})$ ions is also examined. Some common ions reduce the sorption while most of the ions have very little effect. It can be concluded that beach sand may be used as an alternative for the expensive synthetic sorbents.
\end{abstract}

Key words: Cd(II) ions, Sorption, Beach sand, Thermodynamics, Kinetics.

\section{INTRODUCTION}

In recent years public awareness has increased toward the toxic effects of water containing dissolved metal ions. Numerous industrial processes produce effluents containing heavy metal contaminants.

\footnotetext{
*Corresponding author E-mail: Drhasany@gmail.com, iqleemhaider@yahoo.com
} 
Concentration of these pollutants must be reduced to meet ever-increasing legislative standards, recovering the metals where feasible. According to the World Health Organization the metals of most immediate concern are aluminium, chromium, manganese, iron, cobalt, nickel, copper, cadmium, mercury and lead /1/. Cadmium is a toxic element; it has been recognized as a carcinogen for humans $12 \%$. Elevated environmental level of $\mathrm{Cd}(\mathrm{II})$ ions arises from a variety of sources, such as wastewater from metal plating industries, cadmium-nickel batteries, phosphate fertilizer, mining, pigments, stabilizers and alloys $/ 3 /$. Acute cadmium poisoning in humans causes high blood pressure, kidney damage and destruction of testicular tissue and red blood cells /4/. Small amounts of Cd(II) ions are associated with hypertensive diseases. A relation has been found between occupational exposure to cadmium and lung cancer and possibly prostate cancer $15 \%$. The tolerance limits of Cd(II) ions for air are $0.05-0.2 \mathrm{mg} / \mathrm{m}^{3}$, for water $5 \mu \mathrm{g} / \mathrm{dm}^{3}$ and for food $50-150 \mu \mathrm{g} / \mathrm{day}$ 16\%. The search for efficient and economical methods to eliminate or recycle the heavy metals present in industrial effluents has become a necessity $/ 7 /$.

Chemical precipitation, ion-exchange, membrane separation, reverse osmosis, solvent extraction, electrodeposition, electrocoagulation, cementation, adsorption and biosorption have been employed to remove toxic metals from water systems $/ 8 /$. Most of these techniques are of high cost, produce toxic waste, and show inability to meet the government legislation.

The adsorption of heavy metals by a variety of substances has been the subject of many studies, but high cost of the commercially available sorbents makes their large scale applications difficult. Efforts have been made to develop methods for the removal of heavy metals from effluents, using as sorbents natural and waste materials which are abundant and inexpensive, such as: zeolite for lead, cadmium, zinc, chromium, nickel, copper and cobalt /9/, flyash for lead /10/, goethite for chromium, nickel, zinc, copper and cadmium /11/, lignite for copper, cadmium and zinc $/ 12 /$, kaolin and ballclay for cadmium, zinc, chromium, nickel and copper /13/, Haro river sand for antimony /14/, cadmium /15/, and zinc /16/, bed sediment for cadmium /17/, blast furnace waste for zinc and cadmium $/ 18 /$.

The objective of this study is to determine the sorption characteristics of Cd(II) ions onto beach sand from Hawks Bay, Karachi, Pakistan, a locally available cost-effective material as a potential sorbent for the removal of $\mathrm{Cd}(\mathrm{II})$ ions more economically from water bodies.

\section{MATERIALS AND METHODS}

All reagents were of analytical or equivalent grade and all solutions were made in doubly distilled deionized water having conductivity $(0.5 \pm 0.1 \mu \mathrm{S} / \mathrm{cm})$ and $\mathrm{pH}(6.5 \pm 0.2)$. The beach sand was sieved with Ro-tap type mechanical shaker. The mesh size of $300 \mu \mathrm{m}$ is selected as a sorbent because of its larger proportion (45\%) in the total sand. The other mesh sizes separated from the total beach sand are $150 \mu \mathrm{m}$ $25.1 \%, 60017.5 \%, 900 \mu \mathrm{m} 8.4 \%$ and $1950 \mu \mathrm{m} \mathrm{5.6 \%}$. The BET surface area of this mesh size of $300 \mu \mathrm{m}$ is found to be $\sim 1 \mathrm{~m}^{2} \mathrm{~g}^{-1}$, which is of the same order of magnitude as reported for Haro river sand, $1.47 \mathrm{~m}^{2} \mathrm{~g}^{-1}$ $/ 16 \%$.

The X-rays diffraction analysis of the beach sand $(300 \mu \mathrm{m})$ gives calcite $70 \%$, quartz $26 \%$ and aragonite 
$3 \%$ in percentage by weight. A portion of beach sand $(300 \mu \mathrm{m})$ is treated with doubly distilled deionized water, stirred occasionally and left for 2 to $3 \mathrm{~h}$. After stirring the water is decanted and fresh deionised water is added. This procedure is repeated until a colorless supernatant is obtained. The treated sand is heated for 8 to 10 hours at $110^{\circ} \mathrm{C}$. After complete removal of moisture, the sand has been stored in a vacuum desiccator.

\section{PROCEDURE}

A fixed volume $\left(15 \mathrm{~cm}^{3}\right)$ of analyte containing Cd(II) ions $\left(1.78 \times 10^{-5} \mathrm{M}\right)$ is stirred with beach sand (100 $\mathrm{mg}$ ) in a mechanical shaker for $10 \mathrm{~min}$, in a $50 \mathrm{ml}$ polypropylene vessel. The concentration of the analyte solution is determined before and after shaking by Metrohm VA trace analyzer model 747 with VA stand 746. An aliquot $\left(10 \mathrm{~cm}^{3}\right)$ is taken into the VA stand and concentration of $\mathrm{Cd}(\mathrm{II})$ ions is determined on hanging mercury drop electrode at a peak potential of $480 \mathrm{mV}$. The sorption percentages and distribution coefficient $\left(\mathbf{R}_{\mathbf{d}}\right)$ are calculated using the following equations:

$$
\begin{aligned}
& \text { \%Sorption }=\left(\frac{\tilde{C}_{1}-\bar{C}_{e}}{\widetilde{C}_{i}}\right) \times 100 \\
& R d=\frac{C_{i}-C_{e}}{C e} \times \frac{V}{W} \quad\left(\mathrm{~cm}^{3} \mathrm{~g}^{-1}\right)
\end{aligned}
$$

where $\mathrm{C}_{\mathrm{i}}$ is the initial concentration of $\mathrm{Cd}(\mathrm{II})$ ions, $\mathrm{C}_{\mathrm{e}}$ is the equilibrium concentration of $\mathrm{Cd}$ (II) ions in solution, $\mathrm{V}=$ volume of $\mathrm{Cd}(\mathrm{II})$ ions solution $\left(15 \mathrm{~cm}^{3}\right)$ and $\mathrm{W}=$ mass of sorbent (300 $\left.\mathrm{mg}\right)$. The results are the average of at least triplicate measurements at $30 \pm 2{ }^{\circ} \mathrm{C}$, unless specified otherwise. In most cases the precision is around $\pm 2 \%$.

\section{RESULTS AND DISCUSSION}

The sorption of traces of metal ions is influenced by the amount of sorbent, shaking time, shaking speed, concentration of sorbate and nature of electrolytes /19/. Firstly, the shaking speed is optimized in the range 50-200 strokes per minute from deionized water using arbitrarily chosen Cd(II) ions concentration at $1.78 \times 10^{-5} \mathrm{M}$, shaking time 10 minutes, amount of beach sand $100 \mathrm{mg} / 15 \mathrm{~cm}^{2}$. Maximum sorption is achieved around 100 strokes per minute. For further investigations 100 strokes per minute is used as optimized shaking speed.

The influence of the amount of sorbent is examined in the range $100-1000 \mathrm{mg}$ using 10 minutes shaking time and 100 strokes per minute shaking speed and $\mathrm{Cd}(\mathrm{II})$ ions $\left(1.78 \times 10^{-5} \mathrm{M}\right)$ from deionized water. The percent sorption first increases and attains a maximum value $(\sim 58 \%)$ around $300 \mathrm{mg}$, then remains almost constant up to $1000 \mathrm{mg}$. The distribution ratio, $R_{d}$, increases up to $300 \mathrm{mg}$ of sorbent. The volume to mass 
ratio $(\mathrm{V} / \mathrm{W})$ has an appreciable effect on the sorption up to $300 \mathrm{mg}$, whereafter a decline in sorption is observed. Increasing the $\mathrm{V} / \mathrm{W}$ ratio results in a better dispersion of sand particles and the inner surfaces are more exposed. Therefore, for further investigations $300 \mathrm{mg}$ sorbent is used, the results are depicted in Fig.1. A similar trend is observed in the sorption of $\mathrm{Zn}$ (II) ions onto Haro river sand while changing the amount of sorbent under optimized conditions $/ 16 /$.

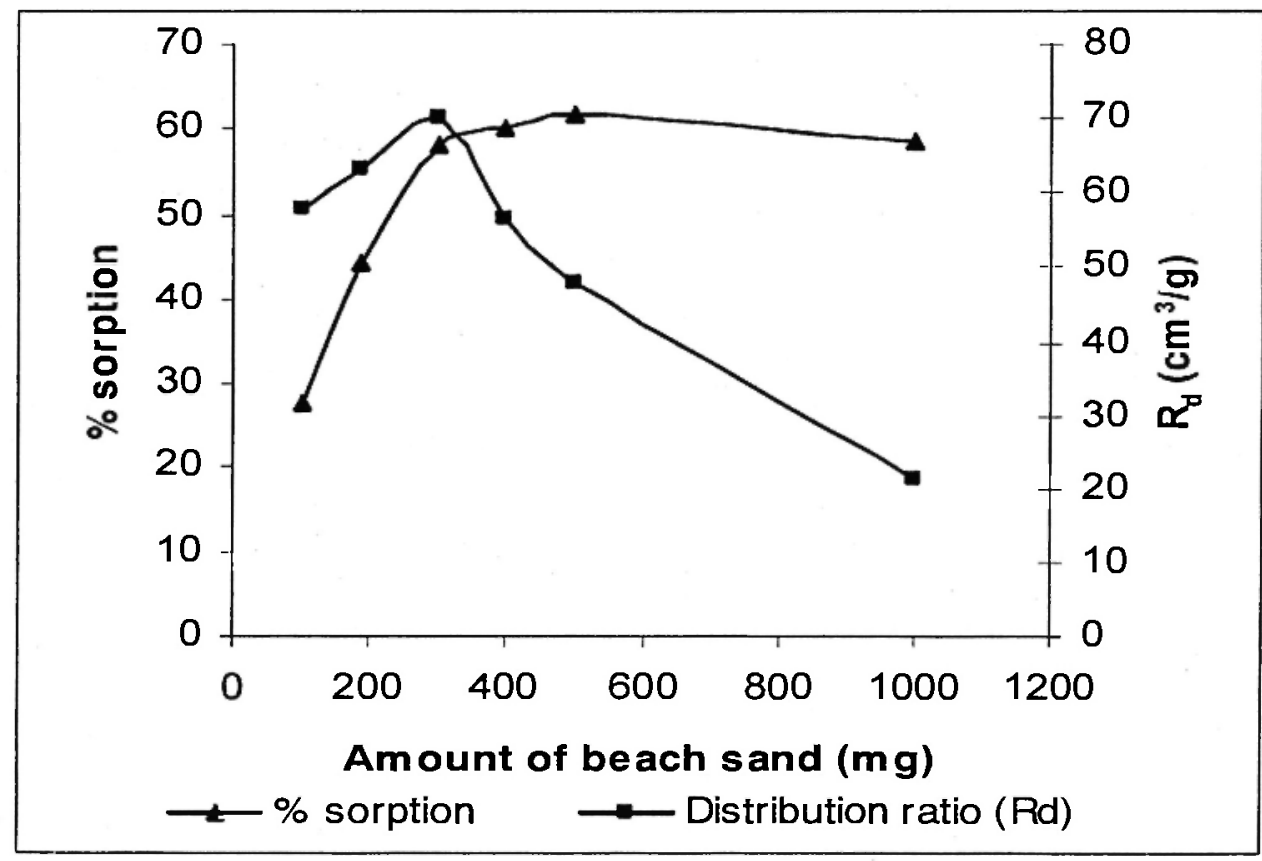

Fig. 1: The effect of beach sand dose on the sorption of Cd(II) ions $\left(6.5 \times 10^{-6} \mathrm{M}\right)$ employing $100 \mathrm{rpm}$ shaking speed and 10 minutes shaking time.

The sorption of $\mathrm{Cd}$ (II) ions $\left(1.78 \times 10^{-5} \mathrm{M}\right)$ is also investigated as a function of nature and concentration of electrolytes. Initially, the sorption is monitored as a function of $\mathrm{pH}(2-10)$ of sorptive solution under the experimental conditions listed. The results are shown in Fig. 2. The sorption percentage registers an increase with an increase in $\mathrm{pH}$. The maximum sorption around $66 \%$ is noticed at $\mathrm{pH}$. At low $\mathrm{pH}(<3)$, the unfavorable high concentration of protons detrimentally affects the uptake of $\mathrm{Cd}$ (II) ions onto beach sand. The solutions of nitric acid, hydrochloric acid and perchloric acid $\left(10^{-4}-10^{-2} \mathrm{M}\right)$, along with deionized water have been investigated as sorptive medium as a function of stirring time. The dilute solutions $\left(10^{-4} \mathrm{M}\right)$ of all three acids gave maximum sorption $57.6 \%$ from $\mathrm{HNO}_{3}, 58.6 \%$ from $\mathrm{HCl}$ and $58.6 \%$ from $\mathrm{HClO}_{4}$, and $66.7 \%$ from deionized water in 20 minutes shaking. The results are shown in Fig. 3. Maximum sorption is noticed from deionised water. The sorption of $\mathrm{Cd}(\mathrm{II})$ ions decreases with increasing molarity of the acid solutions. Therefore in all subsequent experiments, deionised water is used as a sorptive medium. Cd(II) would be present as $\mathrm{Cd}^{2+}$ ions up to $\mathrm{pH} 8$. However, at $\mathrm{pH} 10$ the dominant species would be $\mathrm{Cd}^{2+}(\sim 60 \%), \mathrm{Cd}(\mathrm{OH})^{+}(\sim$ $24 \%)$ and $\mathrm{Cd}(\mathrm{OH})_{2}(\sim 11 \%) / 20 \%$.

The results revealed that $\mathrm{pH}$ is the dominant parameter controlling the adsorption of $\mathrm{Cd}$ (II) ions (Fig. 2). The sorption first increases with the $\mathrm{pH}$ up to around $\mathrm{pH} 6$, thereafter no change in noticed. The variation of 


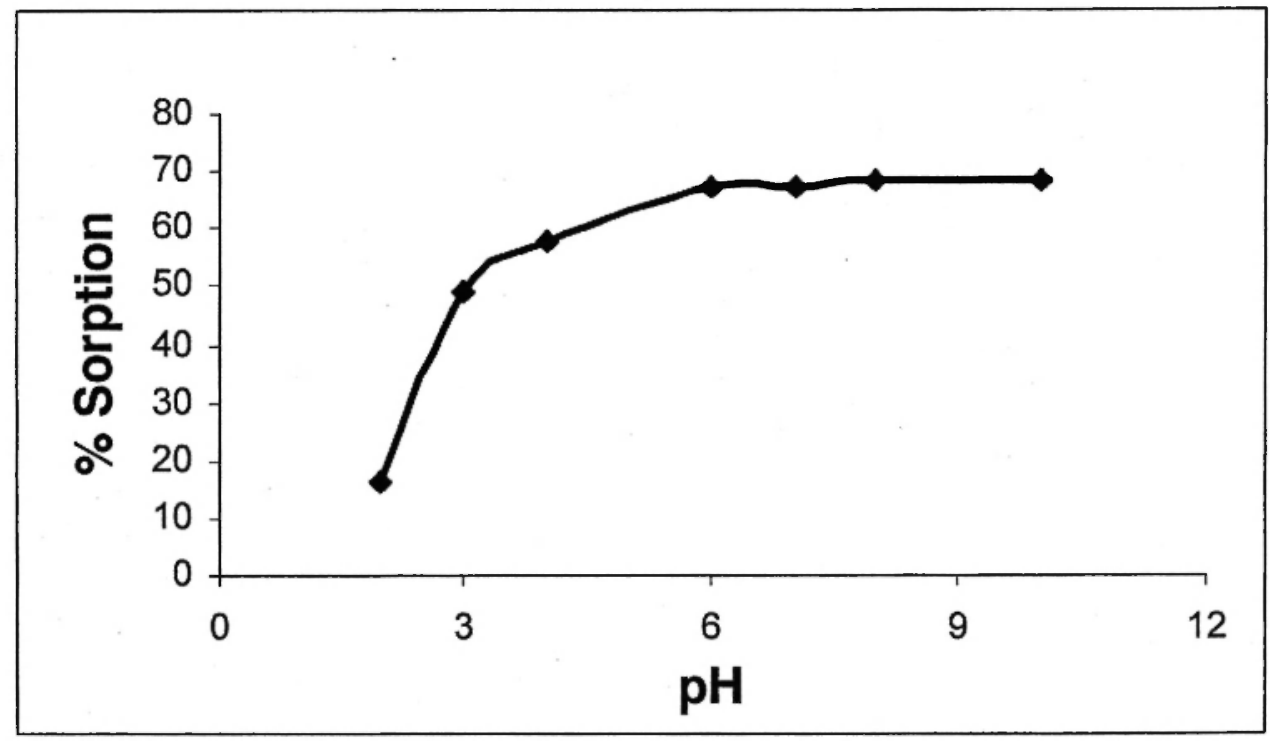

Fig. 2: Variation of \% sorption of $\mathrm{Cd}(\mathrm{II})$ ions onto beach sand with $\mathrm{pH}$. (Amount of beach sand $300 \mathrm{mg} /$ $15 \mathrm{~cm}^{3}$, shaking time 10 minutes, shaking speed $\left.100 \mathrm{rpm}\right) .{ }^{*} \mathrm{Buffer}$ of $\mathrm{pH}(2-3) \mathrm{KCl} / \mathrm{HCl}, \mathrm{pH}(4-6)$ $\mathrm{CH}_{3} \mathrm{COONa} / \mathrm{CH}_{3} \mathrm{COOH}$ and $\mathrm{pH}(8-10) \mathrm{NaCO}_{3} / \mathrm{NaHCO}_{3}$

surface charge with $\mathrm{pH}$ is determined, particularly the point of zero charge $\left(\mathrm{pH}_{\mathrm{pzc}}\right)$ of specific crystal surfaces. The $\mathrm{pH}_{\mathrm{pzc}}$ is fundamentally important to many processes occurring at the mineral-water interface, including dissolution rates $/ 21 /$ and adsorption processes $/ 16 /$. Above the $\mathrm{pH}_{\mathrm{pzc}}$, minerals display negative surface charge, whereas below the $\mathrm{pH}_{\mathrm{pzzc}}$ a positive charge occurs. Quartz, for example, accumulates $\mathrm{pH}-$ dependent surface charge through the dissociation of silanol $(\mathrm{SiOH})$ groups $/ 22 /$. The most common method for determining the $\mathrm{pH}_{\mathrm{pzc}}$ of a mineral is acid-base titration. The $\mathrm{pH}_{\mathrm{pzc}}$ of the beach sand is 8.2 , calculated using computer software protofit, whereas the reported values of $\mathrm{pH}_{\mathrm{pzc}}$ of calcite and quartz are 9.5 and 2.8 respectively /23/. Adsorption of Cd(III) ions onto beach sand may be explained on the basis of the fact that (a) quartz is present in $26 \%$ by weight of the sorbent which has a $\mathrm{pH}_{\mathrm{pzc}}$ of 2.8 , the surface of the quartz is dominated by negative charge on the surface above its $\mathrm{pH}_{\mathrm{pzc}}$. Due to the excess of negative sites metal ions are easily adsorbed on the surface. (b) Calcite which is $70 \%$ by weight of the total beach sand has a $\mathrm{pH}_{\mathrm{pzc}}$ 9.5, and may be the dominating factor for the total properties of the beach sand. Calcite surface should be dominated by positive site below its $\mathrm{pH}$ pzc. But maximum sorption of $\mathrm{Cd}(\mathrm{III})$ ions is noticed around $\mathrm{pH}$ 4-6. This may be explained on the basis of the fact that calcite is a carbonate mineral with a rhombohedral structure. The surface of calcite in water is assumed to be dominated by the uncharged sites $=\mathrm{CaOH}$ and $=$ $\mathrm{CO}_{3} \mathrm{H}$, but ionic sites are also present in the form of $=\mathrm{Ca}\left(\mathrm{OH}_{2}\right)^{+}$and $=\mathrm{CO}_{3}\left(\mathrm{OH}_{2}\right)^{\circ} / 24 /$, The presence of negative site on the surface may also be demonstrated by the removal of $\mathrm{Ca}$ (II) ions into the solution from the sorbent surface at low $\mathrm{pH}$ values, as shown in Fig. 4. The removal of $\mathrm{Ca}$ (II) ions from sorbent surface resulted in an increase in the number of negative sites, which ultimately provides electrostatic attraction for 


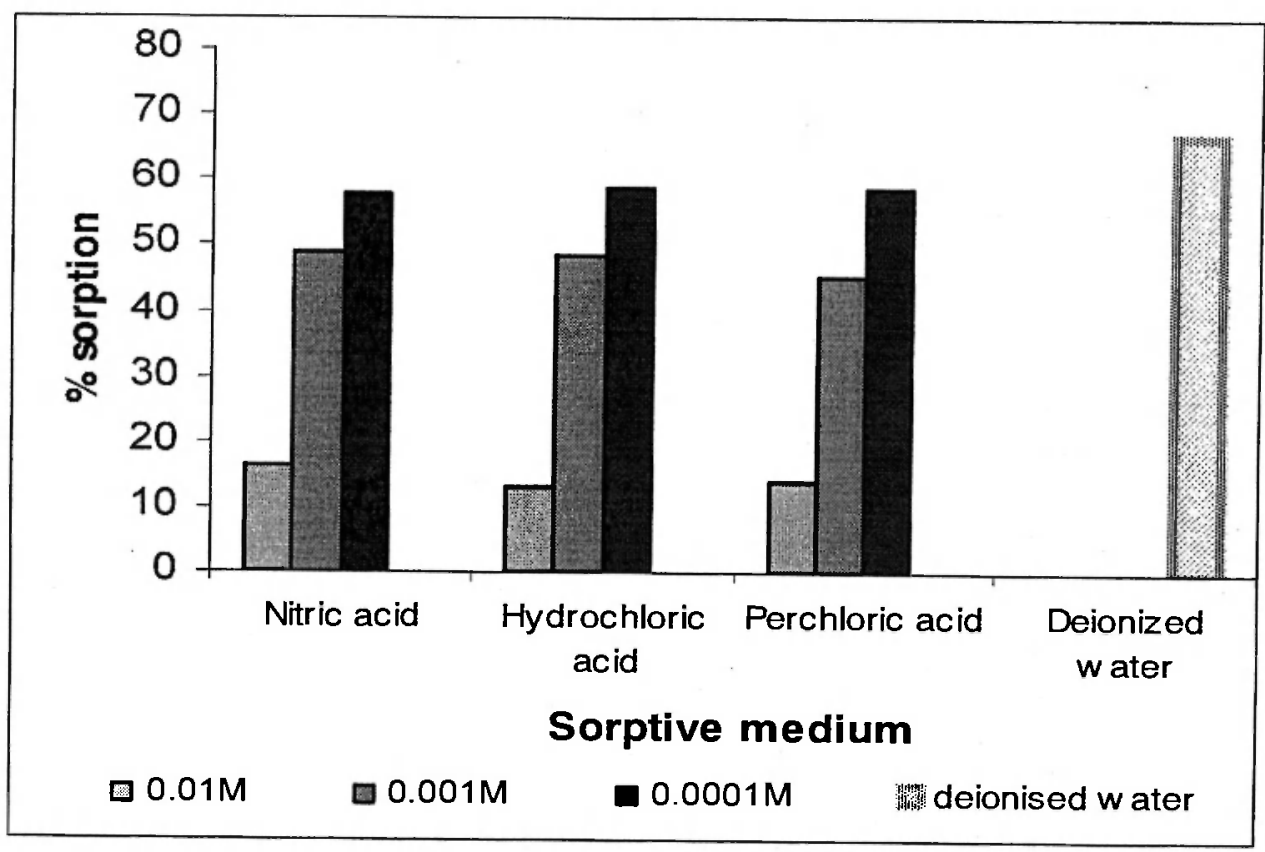

Fig. 3: Sorption of $\mathrm{Cd}(\mathrm{II})$ ions in different media as a function of acid concentration using 20 minutes shaking time and 100 strokes per minutes shaking speed.

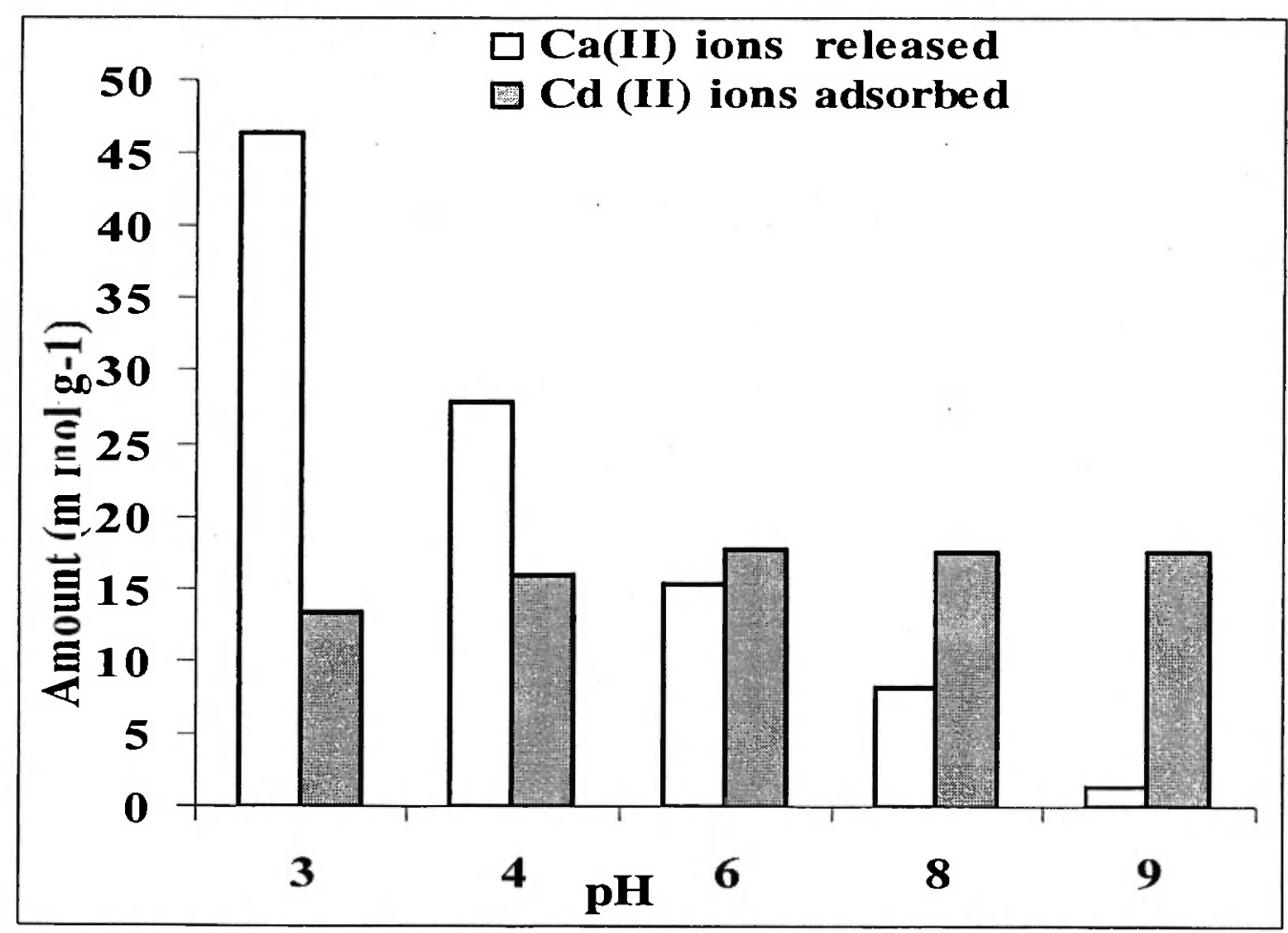

Fig. 4: Effect of $\mathrm{pH}$ on $\mathrm{Ca}(\mathrm{II})$ ions removal from and $\mathrm{Cd}(\mathrm{II})$ ions sorption onto beach sand 
the Cd(III) ions present in the aqueous environment.

Increased sorption with increasing $\mathrm{pH}$ is attributed to decreased $\mathrm{Ca}(\mathrm{II})$ ions concentration and thus reduced competition for available sites. Although $\mathrm{Ca}$ (II) ions concentration decreases with increasing $\mathrm{pH}$, the decrease in sorption of $\mathrm{Cd}(\mathrm{II})$ ions when $\mathrm{pH}$ is increased above 6 indicates that competitive effect with $\mathrm{Ca}$ (II) ions cannot fully explain the sorption trend of $\mathrm{Cd}(\mathrm{II})$ ions onto beach sand.

Studies on the adsorption of amino acids on calcite $/ 25 /$ reveal that calcite, even below its pzc of 9.5 , will have both positive and negative regions of surface charge. Consequently, there are sites near exposed oxygen atoms of the $\mathrm{CO}_{3}$ groups that might take up heavy metal cations. Models of the quartz surface suggest a relatively uniform distribution of terminal oxygen atoms, which achieve a neutral surface charge through hydration. Calcite, by contrast, has both oxygen and calcium atoms at surfaces. Such calcite surfaces likely possess an array of both positive and negative charge centers at any $\mathrm{pH}$.

The concentration of sorbate ions is examined over a 100 -fold concentration of $\mathrm{Cd}(\mathrm{II})$ ions in the range of $1.04 \times 10^{-6}$ to $1.90 \times 10^{-4} \mathrm{M}$ under the experimental condition given in Fig. 5. Dilute aqueous solutions of $\mathrm{Cd}(\mathrm{II})$ ions have been employed as models for low metal concentration wastewater. The sorbed concentration increases with initial concentration of sorbate and attains a constant value around $10^{-4} \mathrm{M}$. A similar trend has been noticed for the sorption of $\mathrm{Cd}$ (II) ions onto Haro river sand /15/ while monitoring the concentration of sorbate onto sorbent surface.

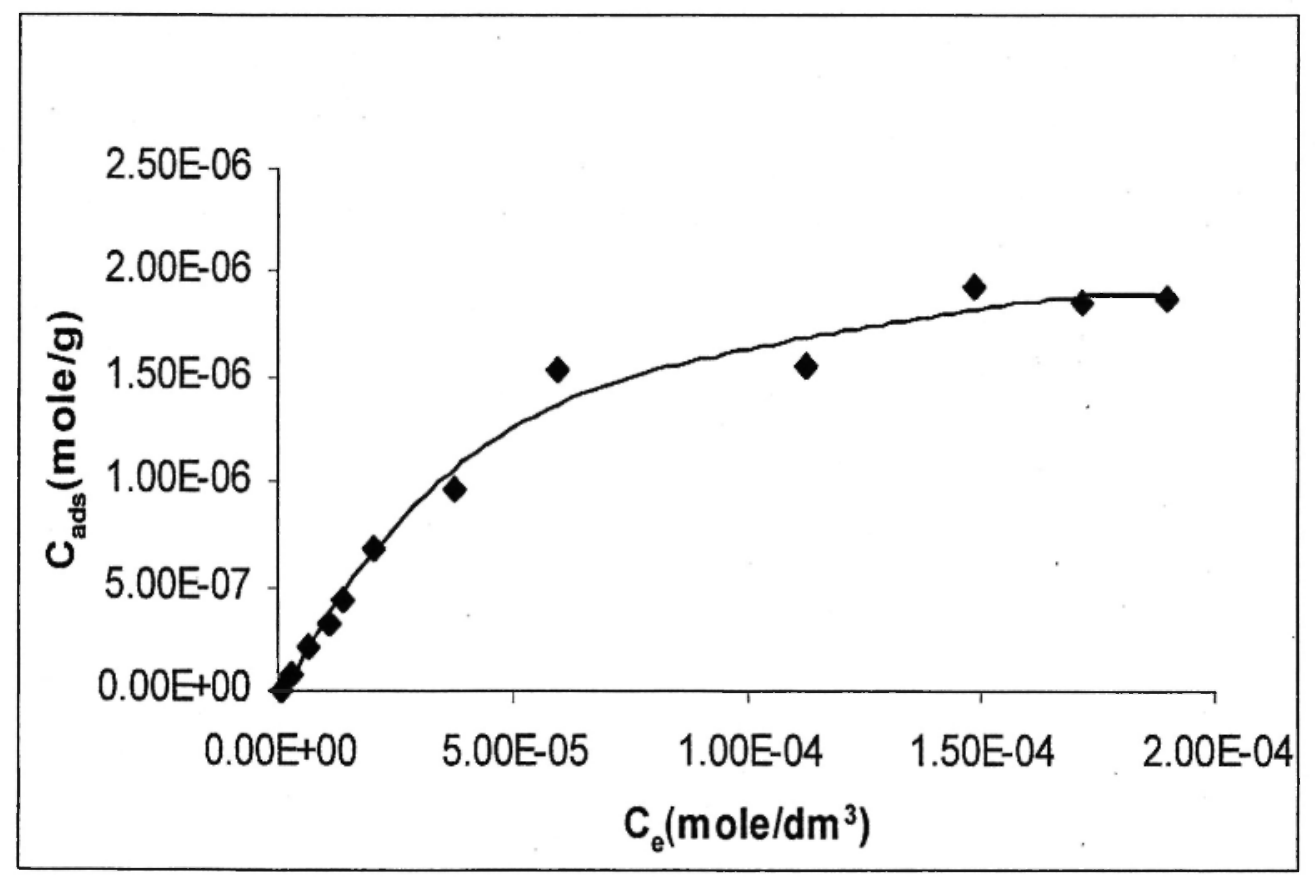

Fig. 5: Influence of concentration of Cd(II) ions on its own sorption onto beach sand. (Amount of beach sand $300 \mathrm{mg}$, shaking time 20 minutes, shaking speed $100 \mathrm{rpm}$ from deionized water as Sorptive medium). 


\section{SORPTION ISOTHERMS}

The sorption data at different temperatures have been subjected to different sorption isotherms, namely Langmuir, Freundlich and Dubinin-Radushkevich (D-R) to assess sorption capacity of $\mathrm{Cd}(\mathrm{II})$ ions. The Langmuir sorption isotherm envisages that all sites are equal and uniform, there is no interaction between neighboring sorbed molecules, there is no steric hindrance between sorbed molecules and incoming ions, and a monolayer is formed at maximum sorption capacity $/ 26 /$. The Langmuir sorption isotherm is tested in the following form:

$$
\frac{C_{e}}{C a d s}=\frac{1}{Q b}+\frac{C_{e}}{Q}
$$

where $C_{e}$ is the residual concentration of sorbate in solution $\left(\mathrm{mole} / \mathrm{dm}^{3}\right)$ at equilibrium, $C_{\text {ads }},=$ amount sorbed (mole/g), $\mathrm{Q}=$ sorption capacity corresponding to complete monolayer coverage and $\mathrm{b}=$ enthalpy dependent sorption equilibrium constant relating to the affinity of binding sites for metal ions. $C_{e} / C_{a d s}$ is plotted against $\mathrm{C}_{e}$ at different temperatures and straight lines are obtained. The Langmuir parameters ( $Q$ and $b$ ) calculated using slope and intercept of the linear plots are tabulated in Table 1. Maximum value of $Q$ and minimum value of $b$ is obtained at $323 \mathrm{~K}$. The value of $\mathrm{Q}$ increases as the sorptive solution temperature is raised, indicating the process to be endothermic. This can further be explained by thermodynamic parameters in the subsequent section. A dimensionless constant $R_{L} / 27$, as given by equation (4), may be evaluated employing

Table 1

Langmuir and Freundlich constants of Cd(II) ions sorption onto beach sand

\begin{tabular}{|c|c|c|c|c|c|c|}
\hline $\mathrm{T}(\mathrm{K})$ & $\begin{array}{c}\mathrm{Q} \\
(\mu \mathrm{mole} / \mathrm{g})\end{array}$ & $\mathrm{b}\left(\mathrm{dm}^{3} / \mathrm{mole}\right)$ & $\mathrm{R}^{2}$ & $1 / \mathrm{n}$ & $\mathrm{A}(\mathrm{m}$ mole/g) & $\mathrm{R}^{2}$ \\
\hline 293 & $5.37 \pm 0.13$ & $\begin{array}{c}(1.41 \pm 0.31) \times \\
10^{4}\end{array}$ & 0.9698 & $0.64 \pm 0.06$ & $0.39 \pm 0.09$ & 0.9424 \\
\hline 303 & $7.51 \pm 0.15$ & $(1.98 \pm 0.63) \times 10^{4}$ & 0.9593 & $0.54 \pm 0.05$ & $0.37 \pm 0.16$ & 0.8856 \\
\hline 313 & $10.4 \pm 0.15$ & $\begin{array}{c}(1.49 \pm 0.16) \times \\
10^{4}\end{array}$ & 0.9785 & $0.62 \pm 0.05$ & $1.30 \pm 0.65$ & 0.9301 \\
\hline 323 & $22.96 \pm$ & $(1.76 \pm 0.14) \times$ & 0.9908 & $0.64 \pm 0.04$ & $3.73 \pm 1.70$ & 0.9625 \\
\hline
\end{tabular}

Langmuir constant $b$ and initial concentration of sorbate, $C_{i} . R_{L}$ is estimated in the range of $0.45-0.99$. This higher value of $\mathrm{R}_{\mathrm{L}}$ indicates reasonable sorption of $\mathrm{Cd}(\mathrm{II})$ ions onto beach sand.

$$
R_{L}=\frac{1}{\left(1+b C_{i}\right)}
$$


The Freundlich isotherm, the most widely used mathematical description of sorption in aqueous solutions, is an empirical expression that encompasses the heterogeneity of the surface and the exponential distribution of sites and their energies $/ 28 /$. The Freundlich equation is tested in the following linearized form:

$$
\log \mathrm{C}_{\mathrm{ads}}=\log \mathrm{A}+\frac{1}{n} \log \mathrm{C}_{\mathrm{e}}
$$

where $C_{a d s}$ and $C_{c}$ have the same meaning as defined earlier, $1 / n=$ Freundlich characteristic constant related to energy or intensity and $\mathrm{A}=$ maximum sorption capacity. $\log \mathrm{C}_{\mathrm{ads}}$ is plotted against $\log \mathrm{C}_{\mathrm{e}}$ at different temperatures, and linear plots are obtained. From the slope and intercept of the plots values of $1 / n$ and $A$ have been estimated using linear regression analysis. The results are listed in Table 1 . A and $1 / \mathrm{n}$ are minimum at lowest temperature investigated. The value of Freundlich parameters at $303 \mathrm{~K}$ are comparable to $\mathrm{A}=1.38 \pm 1.14$ $\mathrm{mmoleg}^{-1}$ and of $1 / \mathrm{n}=0.67 \pm 0.05$ reported for $\mathrm{Cd}$ (II) ions sorption onto Haro river sand $/ 15 /$.

A general correlation of sorption equilibrium for microporous sorbent has been developed by Dubinin and co-workers $/ 29$ / from the ideas put forward by Polanyi $30 /$. The Dubinin-Redushkevich (D - R) model is tested in the following form.

$$
\ln C_{\mathrm{ads}}=\ln \mathrm{X}_{\mathrm{m}}-\beta \varepsilon^{2}
$$

where $C_{a d s}=$ amount sorbed in moleg ${ }^{-1}, X_{m}=$ sorption capacity in the same unit, $\beta=$ a constant related to free energy and $\varepsilon=$ Polanyi potential, which is expressed as

$$
\varepsilon=R T \ln \left(1+\frac{1}{C_{e}}\right)
$$

where $\mathrm{R}$ is the gas constant in $\mathrm{kJ}$ mole $\mathrm{K}^{-1}, \mathrm{~T}$ is the temperature in Kelvin and $\mathrm{C}_{\mathrm{e}}$ as defined earlier. The Polanyi model postulates 'sorption space', close to the sorbent surface where sorption takes place. Polanyi defines the sorption potential ' $\varepsilon$ ' for any molecule within the attractive force field of the solid surface as the work required to remove a molecule to infinity from its location in the sorption space. From the plots of $\ln C_{a d s}$ vs $\varepsilon^{2}$ at different temperatures the values of $\beta, X_{m}$ are determined by the slope and intercept of the linear lines and energy of sorption $E$ is calculated $/ 31 /$ using the following equation. The results are registered in Table 2. The mean sorption energy $E$ is found to vary within a narrow range of $10.13-11.48 \mathrm{k} . \mathrm{J} / \mathrm{mole}$ which is in the range of $8-16 \mathrm{~kJ} /$ mole reported for ion exchange mechanism $/ 32 /$.

$$
E=\frac{1}{\sqrt{-2 \beta}}
$$

The experimental equilibrium data fit all three sorption models. The variation in the sorption capacities estimated in three sorption isotherms may be explained due to assumptions taken into account while deriving these sorption models. In general, the sorption capacities appear to increase with temperature. This can be interpreted by assuming that at higher temperature the number of activated sites has increased, providing 
Table 2

(D-R) characteristic constants for $\mathrm{Cd}(\mathrm{II})$ ions onto beach sand

\begin{tabular}{|c|c|c|c|c|}
\hline$T$ & $\beta\left(\mathrm{kJ}^{2} / \mathrm{mole}^{2}\right)$ & $\begin{array}{c}\mathrm{X}_{\mathrm{m}} \\
(\mu \mathrm{mole} / \mathrm{g})\end{array}$ & $\mathrm{E}(\mathrm{kJ} / \mathrm{mole})$ & $\mathrm{R}^{2}$ \\
\hline 293 & $-0.0049 \pm 0.00044$ & $20.40 \pm 6.30$ & $10.13 \pm 0.45$ & 0.9595 \\
\hline 303 & $-0.0051 \pm 0.00032$ & $29.45 \pm 8.85$ & $10.43 \pm 0.44$ & 0.9256 \\
\hline 313 & $-0.0041 \pm 0.00026$ & $36.30 \pm 8.55$ & $11.06 \pm 0.35$ & 0.9514 \\
\hline 323 & $-0.0038 \pm 0.00019$ & $83.30 \pm 15.71$ & $11.48 \pm 0.28$ & 0.9775 \\
\hline
\end{tabular}

more space for Cd(II) ions to occupy on the sorbent surface and the surfaces in the micropores of the sorbent structure get sufficient amount of activation energy.

\section{KINETICS OF SORPTION}

Mass transfer process can be understood by their kinetics and thermodynamics. Therefore, the change in the sorbed concentration onto sorbent with shaking time is tested by the Morris-Weber equation /33/ in the following form:

$$
\mathrm{q}_{\mathrm{t}}=\mathrm{R}_{\mathrm{id}} \sqrt{t}
$$

where $q_{t}=$ sorbed concentration at time ' $t$ ', $R_{\text {id }}=$ rate constant of intraparticle transport. The plot of $q_{1} v s t^{1 / 2}$ is given in Fig. 6. This is a linear plot with a correlation factor of 0.9352 . The value of $R_{\text {id }}$ calculated from the slope is $80 \pm 3.3 \mu$ mole $^{-1} \mathrm{~min}^{-1 / 2}$.

The kinetics of $\mathrm{Cd}$ (II) ions sorption is subjected to Reichenberg's equation /34/:

$$
F=1-6 / \pi^{2} e^{-B t}
$$

where $\mathrm{Bt}$ can be calculated for each value of $\mathrm{F}$ by the relationship

$$
\mathrm{Bt}=-0.4977-\ln (1-\mathrm{F})
$$

where

$F=q_{t} / q_{e}$ 


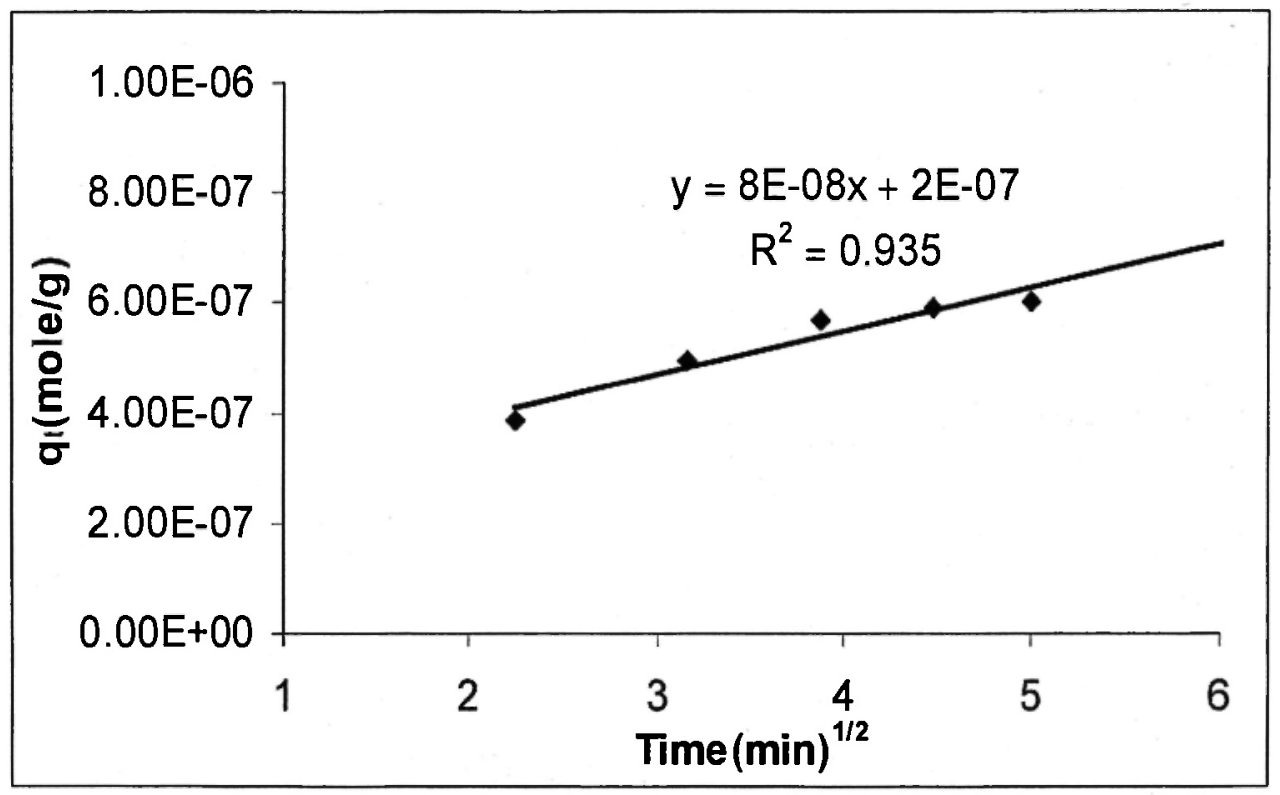

Fig. 6: Validation of Morris - Weber equation for Cd(II) ions sorption onto beach sand.

$\mathrm{q}_{e}$ is the sorbed concentration at equilibrium and $\mathrm{q}_{\mathrm{l}}$ is the sorbed concentration at time ' $\mathrm{t}$ '. The linearity test of Bt versus ' $t$ ', as illustrated in Fig. 7, is employed to distinguish between film and particle diffusioncontrolled mechanisms. The linear Bt versus $\mathrm{t}$ plot does not pass through the origin suggesting a film diffusion sorption process.

The validity of Lagergren'z equation $/ 35 /$ is also tested using the kinetic data

$$
\log \left(q_{e}-q_{t}\right)=\log q_{e}-\frac{h_{t}}{2.30 \dot{3}}
$$

where ' $k$ ' is the first order rate constant. The equation is tested by plotting $\log \left(\mathrm{q}_{\mathrm{e}}-\mathrm{q}_{\mathrm{t}}\right)$ against time ' $\mathrm{t}$ ' in Fig. 8 , yielding a straight line with a correlation factor of 0.9858 . The rate constant $k=0.17 \pm 0.004 \mathrm{~min}^{-1}$ is computed from the slope of the linear plot. This is of the same order of magnitude of $0.18 \mathrm{~min}^{-1}$ estimated for $\mathrm{Ag}$ (I) ions sorption onto polyurethane foam $/ 36 /$.

\section{THERMODYNAMIC STUDIES}

The variation in temperature also affects the sorption of trace metal ions onto solid surfaces. The sorption of $\mathrm{Cd}(\mathrm{II})$ ions onto beach sand is monitored over a temperature range of $293-303 \mathrm{~K}$ under the optimized conditions already chosen. The values of $\Delta \mathrm{H}$ and $\Delta \mathrm{S}$ are calculated from the slope and intercept of the Van't Hoff plot of $\log \mathrm{K}_{\mathrm{c}}$ vs $1 / \mathrm{T}$ ( $\mathrm{T}$ in Kelvin) using equation (13).

$$
K_{c}=\frac{F_{e}}{1-F_{e}}
$$

where $F_{e}$ is the fraction sorbed at equilibrium 


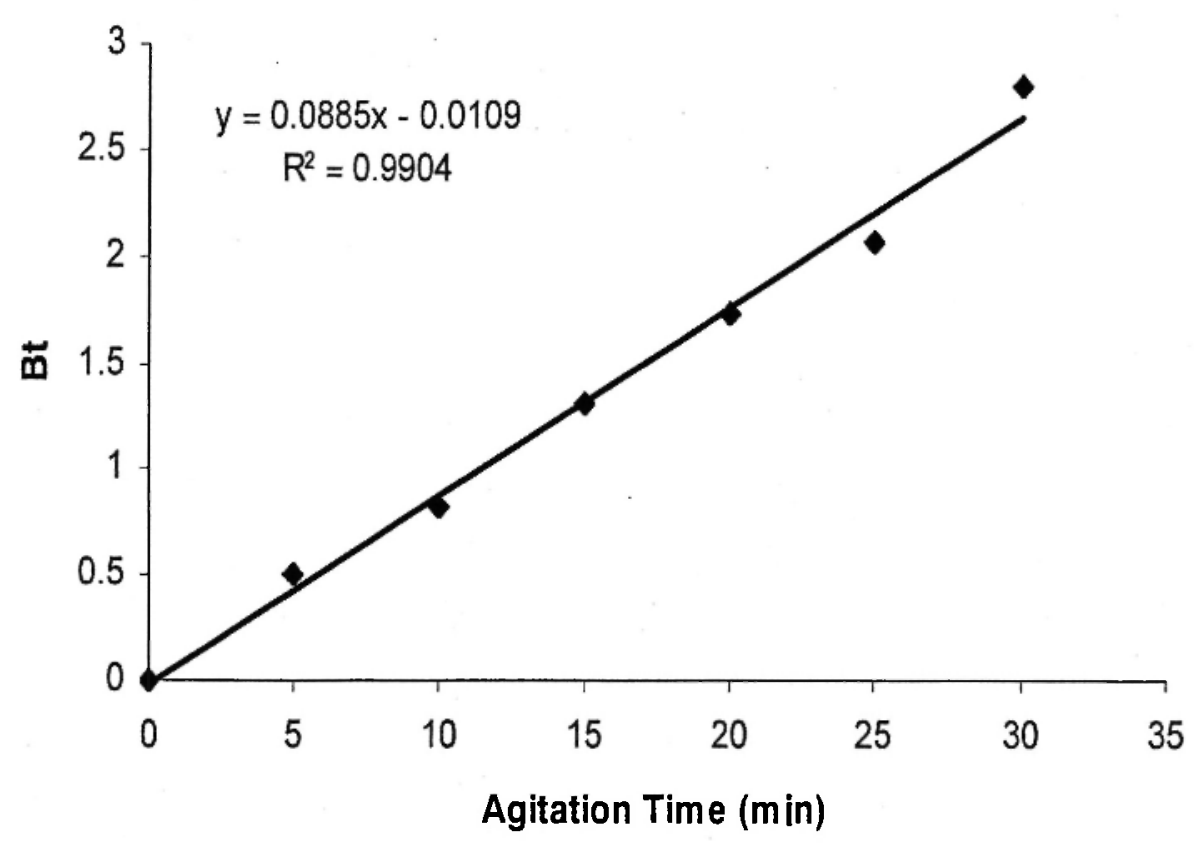

Fig. 7: Reichenberg plot of $\mathrm{Cd}(\mathrm{II})$ ions sorption onto beach sand.

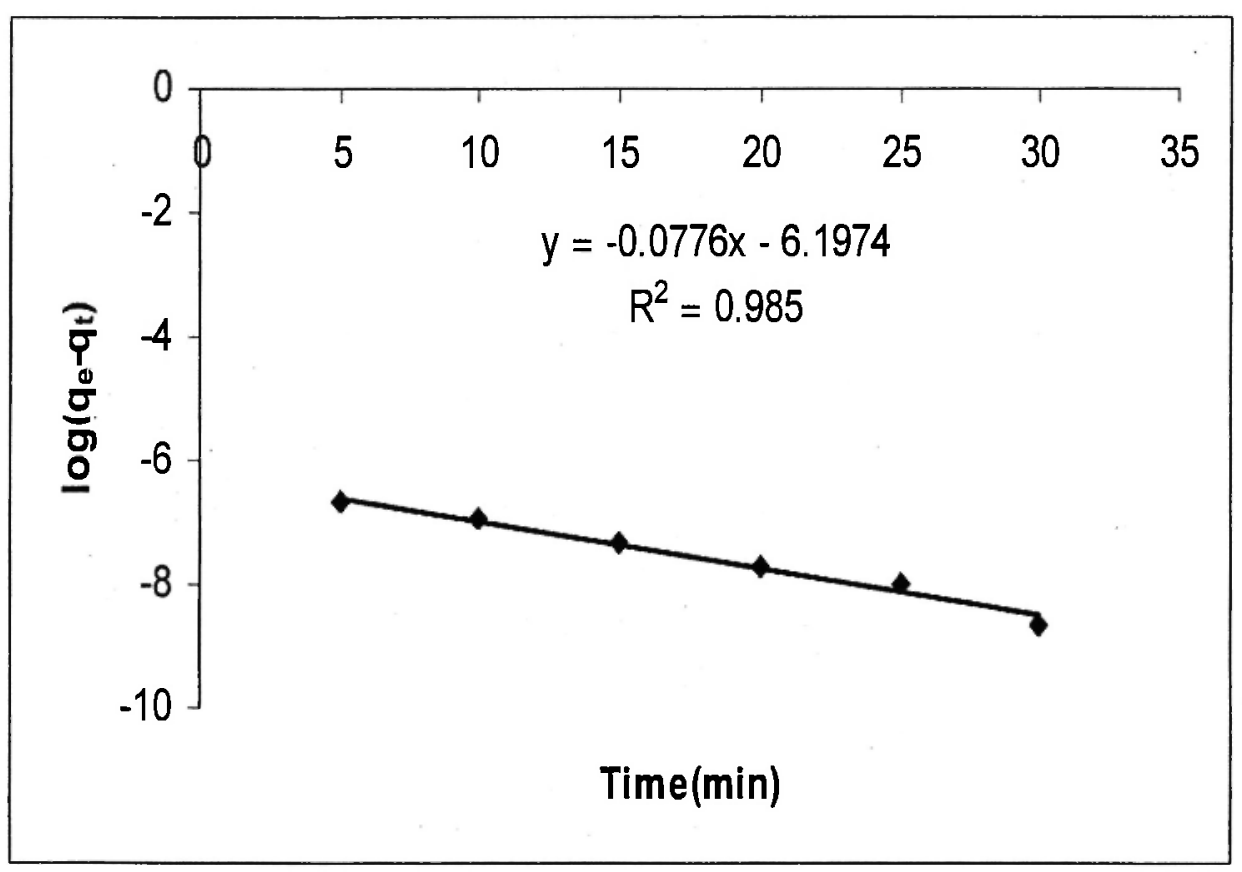

Fig. 8: Application of Lagergren equation for Cd(II) ions sorption onto beach sand. 


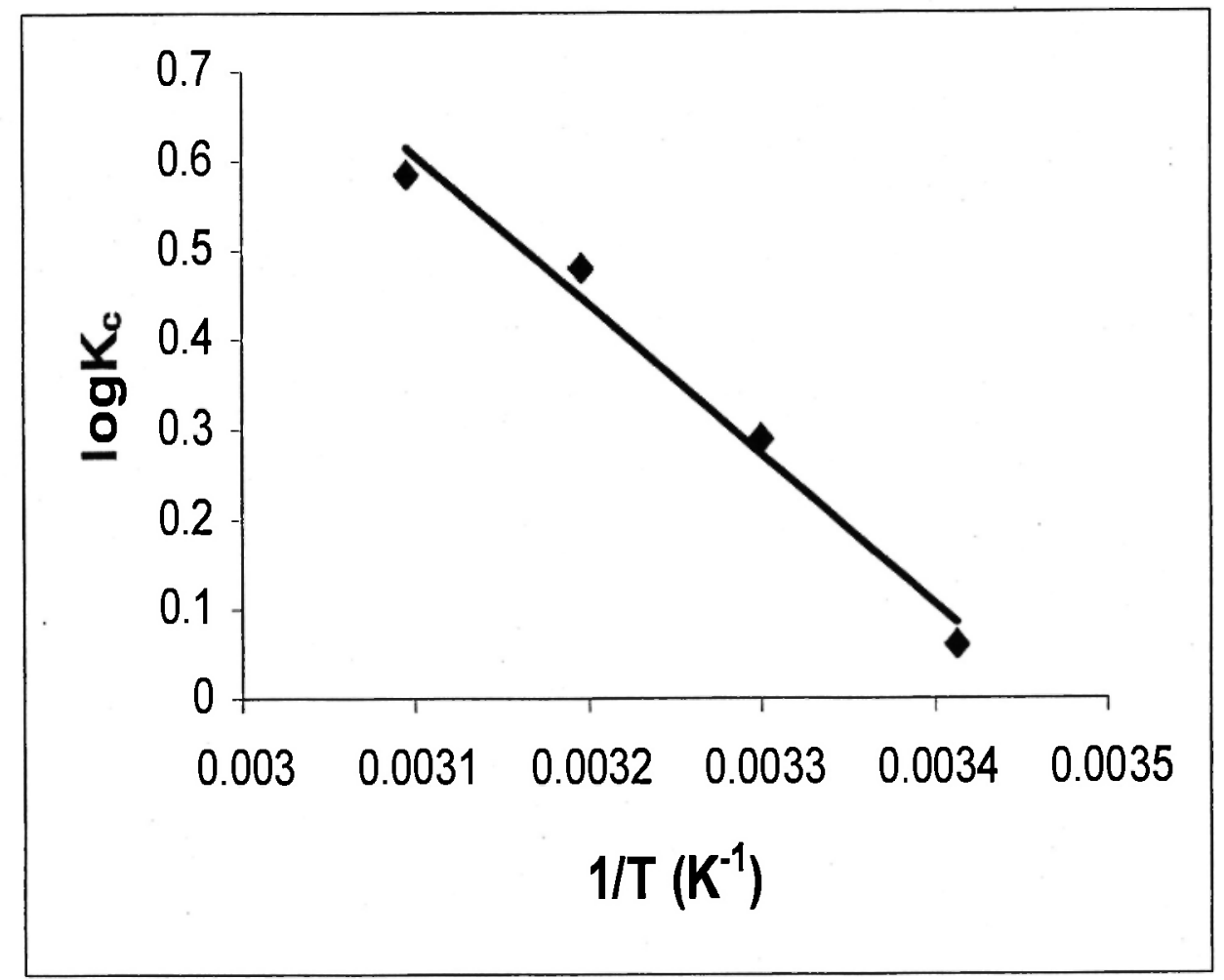

Fig. 9: Variation of $\mathrm{Cd}(\mathrm{II})$ ions sorption with temperature.

$$
\log \mathrm{K}_{\mathrm{c}}=\frac{-\Delta \mathrm{H}}{2.303 \mathrm{RT}}+\frac{\Delta \mathrm{S}}{2.030 \mathrm{R}}
$$

The plot shown in Fig. 9 is linear over the entire range of temperatures investigated. The values of $\Delta \mathrm{G}$ are calculated using equation (14).

$$
\Delta \mathrm{G}=-\mathrm{RT} \ln \mathrm{K}_{\mathrm{c}}
$$

The results are listed in Table.3. The positive value of $\Delta \mathrm{H}$ indicates that the process is endothermic in nature and the negative $\Delta \mathrm{G}$ suggests the spontaneity of the sorption of $\mathrm{Cd}(\mathrm{Il})$ ions onto beach sand. The positive value of entropy change $\left(111 \mathrm{Jmole}^{-1} \mathrm{~K}^{-1}\right)$ suggests the increased randomness at the solid-solution interface during sorption.

The increase in sorption capacity with increase in temperature (Tables 1,2) suggests that chemical sorption plays a dominant role in the whole process. The resulting chemisorptive bond is stronger than that derived from physical Vander Waal forces. 
Table 3

Thermodynamic parameters for Cd(II) ions sorption onto beach sand

\begin{tabular}{|c|c|c|c|c|c|}
\hline \multicolumn{4}{|c|}{$\begin{array}{c}\Delta \mathrm{G} \\
(\mathrm{kJ} / \mathrm{mole})\end{array}$} & $\begin{array}{c}\Delta \mathrm{H} \\
(\mathrm{kJ} / \mathrm{mole})\end{array}$ & $\Delta \mathrm{S}(\mathrm{KJ} / \mathrm{MOLEK})$ \\
\hline $293 \mathrm{~K}$ & $303 \mathrm{~K}$ & $313 \mathrm{~K}$ & $323 \mathrm{~K}$ & & \\
\hline & & & & & \\
\cline { 1 - 2 } & & & & \\
\end{tabular}

\section{INFLUENCE OF DIVERSE ANIONS AND CATIONS}

The influence of different anions and cations on the sorption of $\mathrm{Cd}(\mathrm{II})$ ions is very important, because in the environmental samples the ions other than the targeted ions greatly affect the sorption of the required ion in aqueous medium. Sorption of $\mathrm{Cd}(\mathrm{II})$ ions is studied in the presence of different anions and cations. The anions have been added as their sodium or potassium salts, whereas cations are included as their nitrates or chlorides. The results are shown in Table 4. The nil result refers to the sorption of $\mathrm{Cd}(\mathrm{II})$ ions from sorptive medium without additional diverse anion or cation. $\mathrm{Co}$ (II), $\mathrm{Fe}$ (II), $\mathrm{Cr}(\mathrm{III}), \mathrm{Pb}(\mathrm{II})$ and $\mathrm{Ni}(\mathrm{II})$ ions suppress the sorption of $\mathrm{Cd}(\mathrm{II})$ ions appreciably. This may be due to strong affinity of these cations toward the sorbent surface. Sulphate, thiosulphate, iodide, acetate and EDTA cause substantial decrease in the sorption of $\mathrm{Cd}(\mathrm{II})$ ions onto beach sand. This may be due to higher affinity of anionic complexes of $\mathrm{Cd}$ (II) ions with these ions than that of $\mathrm{Cd}(\mathrm{II})$ ions to the sorbent. Strong complexes of $\mathrm{Cd}(\mathrm{II})$ ions with sulphate, thiosulphate, acetate, iodide and EDTA have been reported in the literature /37-39/.

\section{Table 4}

Sorption of $\mathrm{Cd}(\mathrm{II})$ in the presence of diverse cations and anions.

Nil result indicate sorption of $\mathrm{Cd}(\mathrm{II})$ ions without any diverse ion

\begin{tabular}{|l|c|c|c|}
\hline Cations & \% Sorption & Anions & \% Sorption \\
\hline $\mathrm{Nil}$ & 66.42 & $\mathrm{Nil}$ & 66.42 \\
\hline $\mathrm{Li}(\mathrm{II})$ & 51.23 & $\mathrm{SO}_{4}{ }^{2-}$ & 55.49 \\
\hline $\mathrm{Na}(\mathrm{I})$ & 47.98 & $\mathrm{~S}^{2-}$ & 62.58 \\
\hline $\mathrm{K}(\mathrm{I})$ & 47.89 & $\mathrm{~S}_{2} \mathrm{O}_{3}^{2-}$ & 42.58 \\
\hline $\mathrm{Ca}(\mathrm{II})$ & 61.25 & $\mathrm{CO}_{3}{ }^{2-}$ & 64.58 \\
\hline $\mathrm{Fe}(\mathrm{II})$ & 26.84 & $\mathrm{HCO}_{3}{ }^{-}$ & 61.02 \\
\hline $\mathrm{Co}(\mathrm{II})$ & 23.89 & $\mathrm{Cl}^{-}$ & 63.25 \\
\hline $\mathrm{Ni}(\mathrm{II})$ & 50.25 & $\mathrm{Br}^{-}$ & 59.24 \\
\hline $\mathrm{Zn}(\mathrm{II})$ & 55.68 & $\mathrm{I}^{-}$ & 53.78 \\
\hline $\mathrm{Pb}(\mathrm{II})$ & 40.58 & $\mathrm{CH3COO}$ & 30.58 \\
\hline $\mathrm{Cr}(\mathrm{II})$ & 38.59 & $\mathrm{EDTA}$ & 30.65 \\
\hline
\end{tabular}




\section{REACTION AND MECHANISM}

The beach sand is composed of calcite, quartz, and aragonite. Calcite is rhombohedral in shape. where carbonate ions are arranged in a triangular manner, the oxygens of each carbonate ion occupies three corners of a triangle, while calcium remains in the center of the planes of the triangles. The triangular carbonate groups are the basic building units of all carbonate minerals and are largely responsible for the properties peculiar to the group. Quartz has a tetrahedral structure with oxygen atoms occupying the four corner of a tetrahedron. Aragonite is also calcium carbonate, but with an orthorombic shape; the properties of this component of beach sand also depend on the carbonate /40/. A possible sorption mechanism is proposed for $\mathrm{Cd}$ (II) ions onto beach sand. The presence of negative sites in the structure of the calcite, quartz and aragonite in the form of carbonates and oxides provides affinity for the positively charged $\mathrm{Cd}(\mathrm{II})$ ions in the aqueous solutions as shown below: the electrostatic attractive forces between cadmium cation and the negatively charged surface of the beach sand is likely to dominate the accumulation of $\mathrm{Cd}(\mathrm{II})$ ions onto sorbent surface.

$$
\mathrm{Cd}^{+2}+\mathrm{O}^{-2} \longrightarrow \mathrm{O}^{-}-----\mathrm{Cd}^{+2}-----\mathrm{O}^{-}
$$

\section{CONCLUSIONS}

Beach sand can be used as a potential sorbent to remove $\mathrm{Cd}(\mathrm{II})$ ions from aqueous solutions. The sorption is quite selective because $\mathrm{Cd}(\mathrm{II})$ ions can easily be removed in the presence of diverse common ions from aqueous solutions. Very few of these ions tested have an effect on the sorption. The sorption of Cd(II) ions followed all three sorption isotherms. Sorption capacity generally increased with an increase in temperature. Thermodynamics suggest that the sorption is endothermic and spontaneous in nature. The cost-favorable beach sand may be used to remove traces of $\mathrm{Cd}(\mathrm{II})$ ions or to preconcentrate its very minute amounts from the aqueous media. This sorbent has a potential to treat industrial effluents containing $\mathrm{Cd}(\mathrm{II})$ ions or to clean large volume of solutions contaminated with traces of $\mathrm{Cd}(\mathrm{II})$ ions.

\section{REFERENCES}

1. Guideline for drinking water quality. World Health Organization Geneva, 1984.

2. International Agency for Research on Cancer (IARC), vol 58, Lyons, France,1994.

3. M. Grayson, K. Othmer; Encyclopedia of Chemical Technology. $43^{\text {rd }}$ ed., John Wiley \& Sons, 1978; p. 387.

4. P.P. Sybil; Encyclopedia of Environmental Science, $2^{\text {nd }}$ ed., McGraw Hill. New York, 1980.

5. M.J. Thun, T.M Schnorr; A. B. Smith, J. Natl. Cancer Inst. 75, 325-333 (1985).

6. E. R. Plunkett, Handbook of Industrial Toxicology, Edward Arnold Publication Co. Inc., USA,1987.

7. J. F. Blais, J. L Sasseville, Vecteur Environ. 30, 25-39 (1997). 
8. J. W. Petterson, Environ. Sci. Technol. 25, 1032-1038 (1989).

9. S. K Quki, M Kavannagh. Water Sci. Technol. 39, 115-122, (1999).

10. V. K Gupta, D. Mohan, S. Sharma, Sep. Sci. Technol. 33, $1331-1343$ (1998).

11. K. B. P. N. Jidanasa, C. B. Dissanayake, S. V. R. Weerasooriya, Intern. J. Environ. Studies 48, 7-16 (1995).

12. S. J Allen ; P. A Brown, J. Chem.Tech. Biotechnol. 62, 17-24 (1995).

13. C. Chantawong; N. W. Harvey; V. N. Bushkin, Water Air Soil Pollution. 148, 11-125 (2003).

14. S. M. Hasany, M. H Chaudhary, Appl. Radiat. Isot. 47, 467-471 (1996).

15. S. M Hasany, M. H Chaudhary, J. Radioanal. Nucl. Chem. 247, 335-340 (2001) and reference therein.

16. S. M. Hasany, M. H Chaudhary, Main Group Met. Chem. 29, 279-289 (2003).

17. C.K. Jain, M.K. Sharma, Water, Air, Soil Pollut. 137, 1-1 (2002).

18. V.K. Gupta, A. Rastogi, M.K. Dwivedi, D. Mohan, Sep. Sci. Technol. 32, 2883-2912. (1997).

19. P. Benes, V. Majar, Trace Chemistry of Aqueous Solutions. Elsevier Publishing Co: Amsterdam, 1980; p.175..

20. C.F. Bais, Jr, R.E. Mesmer, The Hydrolysis of Cations. John Wiley \& Sons, New York, 1976, p.300.

21. W. Stumm, Chemistry of the Solid-Water Interface. J. Wiley \& Sons, New York, 1992.

22. G.A. Parks, Journal of Geophysical Research, 89, 3997-4008 (1984).

23. H. Churchill, T. Henry, R.M. Hazen, American Mineralogist, 89, 1048-1055. (2004).

24. C. Jeffroy, A. Foissy, J. Pessello, B. Cabane, J. Colloid Interface Sci. 211, 45-53 (1999).

25. R. Hazen, T. Filley, G. Goodfriend, Proc. Natl. Acad. Sci. USA, 98, 5487-5490 (2001).

26. I. Langmuir, J. Am. Chem. Soc, 40, 1361 (1918).

27. G. McKay; H.S. Blair; J. R. Garlner, J. Appl. Polym. Sci. 27, 3043-3057 (1982)

28. R. Sips, J. Chem. Phys, 16, 690 (1948).

29. B. P. Bering; M. M. Dubinin; V.V . Serpenski, J. Colloid Interface Sci, 38, 185 (1972).

30. M. Polanyi, Trans Faraday Soc. 28, 316 (1932).

31. J. P. Hobson, J. Phys. Chem, 73, 2720 (1969).

32. A. Abusafa and H. Yucel, Sep. Purif. Technol. 28, 103-116 (2002) and reference therein.

33. W. J. Morris, C. I. Weber, J. Sanit. Eng. Division, ASCE, 89, 31 (1963).

34. D. Reichenberg, J Am. Chem Soc. 75, 589 (1953).

35. S. Lagergren, B.K. Handlingar, B. S. Vatens, Kaps Akad Handle 24 (1898).

36. S.M. Hasany, M..M. Saeed, M. Ahmed, Talanta, 54, 89 - 98. (2001)

37. J. A Dean, Large's Handbook of Chemistry $15^{\text {th }}$ ed ; McGrawHill Inc: New York, 1999.

38. J. Kragten, Atlas of Metal Ligand Equilibria in Aqueous Solutions, Ellis Horwood Publisher, Chichester, U.K, 1978.

39. A. E. Martell, L.G. Sillen, Stability Constants of Metal-ion Complexes. Special Publications No. 17 \& 25, Chemical Society, London, (1964 and 1971).

40. C. Klein, C. S. Hurlbut Jr, Manual of Mineralogy. $21^{\text {st }}$ ed : John Wiley \& Sons, Inc: New York, 1993; pp. 129-404. 